\title{
TREATMENT OF COLLOID CYSTS OF THE THIRD VENTRICLE THROUGH NEUROENDOSCOPIC Nd:YAG LASER STEREOTAXIS
}

\author{
Fernando Campos Gomes Pinto', Maria Cristina Chavantes', \\ Erich Talamoni Fonoff', Manoel Jacobsen Teixeira'
}

\begin{abstract}
Objective: Colloid cysts (IIIVT CC) are benign neuroepithelial cysts located in the anterior third ventricle. The authors propose the use of Nd:YAG laser stereotactic neuroendoscopic for guided resection of the third ventricle colloid cysts. Method: Eleven patients presented third ventricle colloid cysts and were treated by Nd:YAG laser guided with stereotactic endoscopy $(n=7)$, stereotactic endoscopy $(n=3)$ or stereotactly guided puncture ( $n=1)$. The patients were followed prospectively (average 33 months, range 19-64 months). The clinical data, neuroimaging findings, hospitalization stay, outcomes and complications of the method were evaluated. Results: All patients presented headache; six had papilledema, one had gait disturbance and one had third-nerve palsy. Neuroimaging showed hydrocephalus and a IIIVT CC with 14.4-mm mean diameter. After surgery all patients presented clinical and image improvement. Only two patients presented transient morbidities that were easily treated: One had diabetes insipidus that lasted for two days and was treated with a single dose of DDAVP, and another had chemical aseptic meningitis, probably due to the contact of the cyst content with the CSF. This patient was treated with antibiotics and corticosteroids with complete resolution of the problem without sequels. The other patients were discharged from the hospital $48 \mathrm{~h}$ after surgery. Conclusion: The stereotactic neuroendoscopy-guided procedure with Nd:YAG laser allowed the complete removal of the third ventricle colloid cysts, without definitive morbidities, sequels or recurrence of the lesion.
\end{abstract}

KEY WORDS: laser, neuroendoscopy, third ventricle, colloid cysts.

Tratamento do cisto colóide do terceiro ventrículo por neuroendoscopia estereotática com laser Nd:YAG

Resumo - Objetivo: Os cistos colóides (CC IIIVT) são lesões neuroepiteliais benignas localizadas anteriormente no terceiro ventrículo. Nós propomos a ressecção neuroendoscópica com o uso do Nd:YAG laser guiada por estereotaxia. Método: Onze pacientes portadores de cisto colóide do terceiro ventrículo foram tratados por neuroendoscopia estereotática com laser Nd:YAG $(n=7)$, neuroendoscopia estereotática $(n=3)$ ou punção estereotática ( $n=1)$ e foram seguidos prospectivamente (média 33 meses, variação 19-64 meses). Os dados clínicos, achados de neuroimagem, tempo de hospitalização, evolução e complicações referentes à técnica foram avaliadas. Resultados: Todos pacientes apresentaram cefaléia; seis tiveram papiledema, um apresentou distúrbio de marcha e um apresentou paresia do terceiro nervo. Os exames de neuroimagem evidenciaram hidrocefalia e CC IIIVT com diâmetro médio de 14,4 mm. Depois da cirurgia todos os pacientes apresentaram melhora clínica e de imagem. Apenas dois pacientes apresentaram morbidades transitórias que foram facilmente tratadas: um apresentou diabetes insipidus que durou dois dias e foi tratada com uma única dose de DDAVP, o outro apresentou meningite química asséptica, provavelmente pelo contato do conteúdo do cisto com o líquor. Este paciente recebeu antibióticos e corticóide com resolução completa do problema. Os outros pacientes receberam alta hospitalar após $48 \mathrm{~h}$. Conclusão: A ressecção neuroendoscópica com o uso do Nd:YAG laser guiada por estereotaxia possibilitou a remoção completa do cisto colóide sem morbidades definitivas, seqüelas ou recorrência da lesão.

PALAVRAS-CHAVE: laser, neuroendoscopia, terceiro ventrículo, cisto colóide.

'Division of Functional Neurosurgery of the Institute of Psychiatry, Hospital das Clínicas, University of São Paulo, São Paulo SP, Brazil; '2Laser Medical Center of the Institute of Heart of the Medical School, University of São Paulo, São Paulo SP, Brazil. 
Colloid cysts are benign unilocular cysts of neuroepithelial origin, consistently located in the anterior third ventricle $^{1,2}$. They represent 0.2 to $2.0 \%$ of all intracranial tumors $^{3-5}$. Most of the cysts reported in the literature are symptomatic. The current consensus is that symptomatic colloid cysts should be treated; however, the treatment of asymptomatic colloid cysts without ventricular enlargement remains a controversial issue.

Several therapeutic options have been proposed for its treatment: non-surgical treatment with control of sequential images, shunting of cerebrospinal fluid, stereotactic aspiration of its content, microsurgical removal, stereotactic guided endoscopy, neuroendoscopy, stereotactically-guided craniectomy and neuronavigation-assisted endoscopy ${ }^{2-13}$.

Since 1960, $\mathrm{CO}_{2}$, Argon, Nd:YAG and Diode lasers have been used in neurosurgical procedures'.

We propose the use of stereotactic-guided neuroendoscopy for the treatment of third ventricle colloid cysts and describe its use in eleven cases with Nd:YAG laser. This technique will be described herein.

\section{METHOD}

Eleven Caucasian patients, five males and six females, with ages ranging from 26 yrs to $67 y$ rs (mean 38 years old), with obstructive hydrocephalus due to third ventricle colloid cysts have been referred to the Hospital das Clínicas, University of São Paulo, Brazil, from 1992 to 2007 (period of fifteen years).

All patients presented obstructive hydrocephalus and thirdventricle colloid cyst at the $\mathrm{CT}$ and MRI images. The mean diameter of the lesion ranged from $7 \mathrm{~mm}$ to $22 \mathrm{~mm}$ (mean $14.4 \mathrm{~mm}$ ). One patient with bilateral ventricular shunt presented slit ventricle and a $15-\mathrm{mm}$ third ventricle colloid cyst.

Seven patients were treated with Nd:YAG laser neuroendoscopic stereotactly guided, three patients were treated with neuroendoscopic stereotactly guided, but without Nd:YAG laser and one patient was treated with stereotactly guided puncture for colloid cysts removal. The stereotactic frame (Micromar, Diadema, São Paulo, Brazil) was fixed to the head of the patients under local anesthesia ( $2 \%$ lidocaine) and a stereotactic reconstruction of the brain and lesion was performed. The trajectory was constructed with CT and MRI aiming at the avoidance of the fornix, intern cerebral vein, septal veins and the center of the lesion was used as the target. A right frontal 18-mm trephination was used and a rigid neuroendoscope with a $30^{\circ}$ lens (ChavantesZamorano Neuroendoscopy Storz ${ }^{\circledR}$ or Aesculap ${ }^{\circledR}$ ) was attached to the stereotactic frame and its axis directed to the center of the lesion. We used in all surgeries, through the neuroendoscope working channel, a Nd:YAG Laser, C.W. (Surgilase ${ }^{\circledR}$ ) with a 600$\mu \mathrm{m}$ diameter silica fiber; contact mode was used in all cases.

Table 1 shows the treatment protocol. Table 2 shows the patients' age, gender, symptoms and CT/MRI findings at admission, operative procedures, date of surgery, morbidity, follow-up period, current clinical status and CT/MRI postoperative images.

\section{RESULTS}

All patients presented severe, constant or episodic headaches as the first symptom; six had papilledema, one had gait disturbance and another, diplopia.

A rigid neuroendoscope with a $30^{\circ}$ lens and four channels (Aesculap ${ }^{\circledR}$ ) was used and in the first case, the Chavantes-Zamorano neuroendoscope was used to monitor the intracranial pressure.

The neuroendoscopic approach was preferably carried out through the right lateral ventricle or through the more enlarged lateral ventricle (Fig 1). After the insertion of the neuroendoscope into the lateral ventricle, the anatomic landmarks such as septal vein, thalamostriate vein, choroid plexus and the foramen of Monro were identified. The capsule of the cyst was then identified and coagulat-

\section{Table 1. Treatment protocol.}

1. Diagnosis based on clinical presentation and CT/MRI with hydrocephalus and colloid cyst in third ventricle.

2. Neuropsychological examination.

3. Stereotomographic localization of the lesion.

4. Local or general anesthesia.

5. Neuroendoscopy guided by stereotaxis (frontal keyhole approach; right ventricle or the largest one) with $30^{\circ}$ lens, identification of the lateral ventricle and the foramen of Monro.

6. Identification of the colloid cyst capsule

7. Small hole in this capsule with Nd:YAG laser beam.

8. Aspiration of the content with a cannula.

9. Nd:YAG laser to vaporize the capsule with contact/non-contact shots.

10. First post-operative day CT.

11. Discharge after 48 hours.

12. CT: first post-operative period, 3 months, 6 months; neuropsychological examination and afterward, annual MRI images of the brain. 
Table 2. Patients' age, gender, symptoms and CT/MRI findings at admission, operative procedures, date of surgery, morbidity, followup period, current clinical status and CT/MRI postoperative images.

\begin{tabular}{|c|c|c|c|c|c|c|c|c|}
\hline Patient & $\begin{array}{c}\text { Age (yrs) / } \\
\text { gender }\end{array}$ & $\begin{array}{l}\text { Symptoms } \\
\text { at admission }\end{array}$ & $\begin{array}{l}\text { CT/MRI findings } \\
\text { at admission }\end{array}$ & $\begin{array}{l}\text { Surgical } \\
\text { procedure }\end{array}$ & Morbidity & $\begin{array}{l}\text { Follow up } \\
\text { (mo) }\end{array}$ & $\begin{array}{c}\text { Current } \\
\text { clinical status }\end{array}$ & $\begin{array}{l}\mathrm{CT} / \mathrm{MRI} \\
\text { control }\end{array}$ \\
\hline 1 & $32 / f$ & $\begin{array}{c}\text { Headache } \\
\text { and vomiting }\end{array}$ & $\begin{array}{l}\text { Hydrocephalus, } \\
12 \mathrm{~mm} \text { cyst }\end{array}$ & $\begin{array}{l}\text { Endo+Laser+ } \\
\text { Stereotaxis } \\
\text { Local anesthesia }\end{array}$ & $\begin{array}{l}\text { Fever } \\
1^{\text {st }} \text { day }\end{array}$ & 54 & Asymptomatic & $\begin{array}{l}\text { No lesion, no } \\
\text { hydrocephalus }\end{array}$ \\
\hline 2 & $35 / f$ & $\begin{array}{l}\text { Headache, } \\
\text { vomiting, eye } \\
\text { sight blurring }\end{array}$ & $\begin{array}{l}\text { Hydrocephalus, } \\
14 \text { mm cyst }\end{array}$ & $\begin{array}{l}\text { Endo+ Laser+ } \\
\text { Stereotaxis } \\
\text { Local anesthesia }\end{array}$ & $\begin{array}{c}\text { Headache, } \\
\text { and fever } \\
1^{\text {st }} \text { day }\end{array}$ & 40 & Asymptomatic & $\begin{array}{l}\text { No lesion, no } \\
\text { hydrocephalus }\end{array}$ \\
\hline 3 & $26 / f$ & $\begin{array}{l}\text { Headache, } \\
\text { vomiting, eye sight } \\
\text { blurring, bilateral } \\
\text { ventricular shunt/ } \\
\text { slit ventricle }\end{array}$ & $\begin{array}{l}\text { Slit ventricle, } \\
15 \text { mm cyst }\end{array}$ & $\begin{array}{l}\text { Endo+Stereotaxis } \\
\text { Local anesthesia }\end{array}$ & No & 50 & Asymptomatic & $\begin{array}{l}\text { No lesion, } \\
\text { slit ventricle }\end{array}$ \\
\hline 4 & $39 / m$ & $\begin{array}{l}\text { Headache, } \\
\text { vomiting, eye } \\
\text { sight blurring }\end{array}$ & $\begin{array}{l}\text { Hydrocephalus, } \\
16 \text { mm cyst }\end{array}$ & $\begin{array}{l}\text { Endo+ Stereotaxis } \\
\text { General anesthesia }\end{array}$ & No & 64 & Asymptomatic & $\begin{array}{c}\text { No lesion, } \\
\text { Normal } \\
\text { ventricles }\end{array}$ \\
\hline 5 & $52 / m$ & $\begin{array}{l}\text { Headache, } \\
\text { vomiting, eye } \\
\text { sight blurring }\end{array}$ & $\begin{array}{l}\text { Hydrocephalus, } \\
17 \text { mm cyst }\end{array}$ & $\begin{array}{c}\text { Local anesthesia+ } \\
\text { Stereotaxis }\end{array}$ & No & 28 & Asymptomatic & $\begin{array}{c}\text { No lesion, } \\
\text { Normal } \\
\text { ventricles }\end{array}$ \\
\hline 6 & $31 / m$ & $\begin{array}{c}\text { Headache, diplopia } \\
\text { due to left III } \\
\text { nerve syndrome }\end{array}$ & $\begin{array}{l}\text { Hydrocephalus, } \\
\text { 10-mm cyst }\end{array}$ & $\begin{array}{c}\text { Endo+ Laser+ } \\
\text { Stereotaxis } \\
\text { General anesthesia }\end{array}$ & $\begin{array}{l}\text { Chemical } \\
\text { meningitis }\end{array}$ & 23 & Asymptomatic & $\begin{array}{c}\text { No lesion, } \\
\text { Normal } \\
\text { ventricles }\end{array}$ \\
\hline 7 & $35 / f$ & $\begin{array}{l}\text { Headache eye } \\
\text { sight blurring }\end{array}$ & $\begin{array}{l}\text { Hydrocephalus, } \\
\text { 17-mm cyst }\end{array}$ & $\begin{array}{c}\text { Endo+ Laser+ } \\
\text { Stereotaxis } \\
\text { General anesthesia }\end{array}$ & No & 23 & Asymptomatic & $\begin{array}{c}\text { No lesion, } \\
\text { Normal } \\
\text { ventricles }\end{array}$ \\
\hline 8 & $36 / f$ & $\begin{array}{l}\text { Headache, gait } \\
\text { disturbance }\end{array}$ & $\begin{array}{l}\text { Hydrocephalus, } \\
\text { 17-mm cyst }\end{array}$ & $\begin{array}{c}\text { Endo+ Laser+ } \\
\text { Stereotaxis } \\
\text { General anesthesia }\end{array}$ & No & 22 & Asymptomatic & $\begin{array}{c}\text { No lesion, } \\
\text { Normal } \\
\text { ventricles }\end{array}$ \\
\hline 9 & $61 / m$ & Headache & $\begin{array}{l}\text { Hydrocephalus, } \\
\text { 7-mm cyst }\end{array}$ & $\begin{array}{l}\text { Endo+ Stereotaxis } \\
\text { General anesthesia }\end{array}$ & No & 20 & Asymptomatic & $\begin{array}{c}\text { No lesion, } \\
\text { Normal } \\
\text { ventricles }\end{array}$ \\
\hline 10 & $41 / m$ & Headache & $\begin{array}{l}\text { Hydrocephalus, } \\
\text { 11-mm cyst }\end{array}$ & $\begin{array}{c}\text { Endo+ Laser+ } \\
\text { Stereotaxis } \\
\text { General anesthesia }\end{array}$ & $\begin{array}{l}\text { Transient } \\
\text { diabetes } \\
\text { insipidus }\end{array}$ & 20 & Asymptomatic & $\begin{array}{c}\text { No lesion, } \\
\text { Normal } \\
\text { ventriclesa }\end{array}$ \\
\hline 11 & $40 / f$ & $\begin{array}{l}\text { Headache, eye } \\
\text { sight blurring }\end{array}$ & $\begin{array}{l}\text { Hydrocephalus, } \\
\text { 22-mm cyst }\end{array}$ & $\begin{array}{c}\text { Endo+ Laser+ } \\
\text { Stereotaxis } \\
\text { General anesthesia }\end{array}$ & No & 19 & Asymptomatic & $\begin{array}{c}\text { No lesion, } \\
\text { Normal } \\
\text { ventricles }\end{array}$ \\
\hline
\end{tabular}

ed with contact Nd:YAG laser (20 Watts); a thin catheter was inserted through the working channel of the neuroendoscope and used for aspiration of the colloid content of the cyst. When the cyst became empty, the capsule was totally ablated by applying a Nd:YAG laser through a contact silica fiber inserted through the working channel of the neuroendoscope (Fig 2). Extra care was necessary with the laser application, in order to prevent damage to the hypothalamus and the fornix. Bleeding points were easily controlled with the application of contact laser.
All patients had CT scanning of the brain during the first 24 hours after surgery. No tumor and resolution of the preoperative hydrocephalus was observed in the acquired images.

One patient developed transient diabetes insipidus on the first postoperative day and was treated with a single dose of DDAVP. His discharge occurred five days later, without any symptoms or diabetes insipidus. One patient had chemical aseptic meningitis, probably due to the contact of the cyst content with the CSF. This pa- 


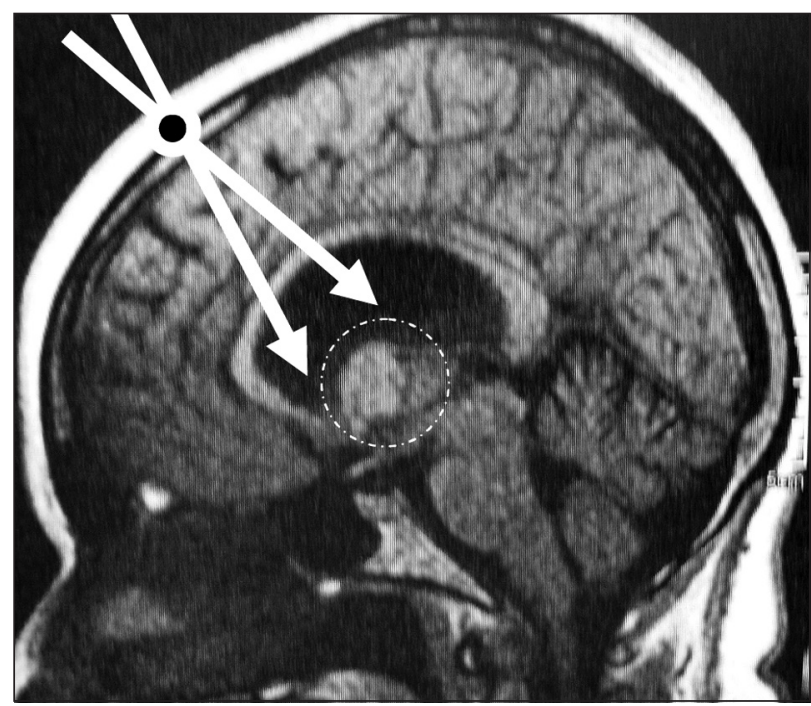

Fig 1. Neuroendoscopic trajectory towards of the upper aspect of the colloid cyst through one frontal burr hole. The stereotactic procedure defines the limits of boundaries of the cyst and its anatomical relationship with the floor of the third ventricle, foramen of monro, veins, hipothalamus and fornix. The accuracy and safety of Nd:YAG laser ressection was increased by the neuroendoscopic view and stereotaxis guiadance.

tient was treated with antibiotics and corticosteroids with complete resolution of the problem without sequels.

Other patients were discharged from the hospital 48 $\mathrm{h}$ after the surgery; including two patients who had fever once time $24 \mathrm{~h}$ after procedure.

\section{Follow up}

All patients had CT or MRI scanning of the head after the third, sixth and $12^{\text {th }}$ month of the postoperative period. After the sixth month, all the patients underwent neuropsychological examination, without memory deficit. None of them presented recurrence of the lesion and

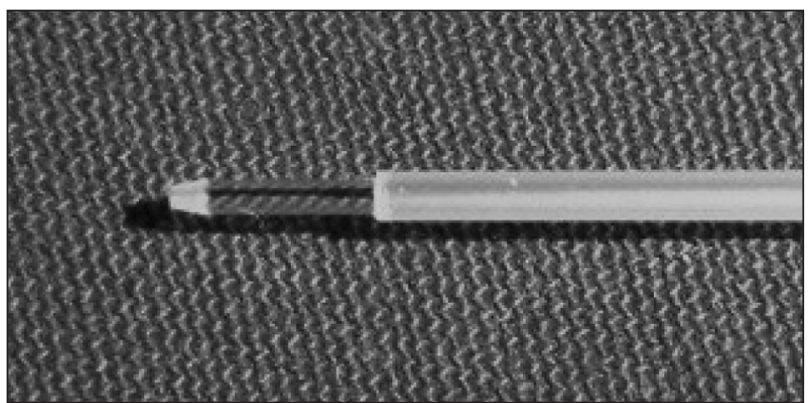

Fig 2. The fiber of silica for Nd:YAG laser (diameter $=600 \mu \mathrm{m}$ ).

of the hydrocephalus (Fig 3). The patients were followed prospectively (average 33 months, range 19-64 months).

\section{DISCUSSION}

Symptomatic colloid cysts are usually diagnosed in patients in their $2^{\text {nd }}$ to $5^{\text {th }}$ decades of life and equally affect both sexes. They can be asymptomatic, or present as paroxysmal headache with different severity degrees according to the position of the head, drop attacks, progressive or fluctuating dementia, clinical-like 'normal pressure hydrocephalus', or sudden death due to obstruction of the foramen of Monro followed by acute hidrocephalus ${ }^{4,5}$. Non-contrast CT displays colloid cysts as a hypo-, iso-, or hyperdense, homogeneous and well-delineated round or ovoid masses. Contrast enhancement is absent or minimal. They are found incidentally at a rate of 1 in 1,000 CT. In MRI images, they present as homogeneously to heterogeneously hypointense or hyperintense masses in $\mathrm{T} 1$ and $\mathrm{T} 2$ weighted acquisitions. The outstanding characteristic is a sharply outlined round or ovoid mass in the anterior and superior third ventricle, near or at the foramen of Monro regions. Hydrocephalus is observed in most patients ${ }^{4}$.

The management of colloid cysts remains controversial. Several therapeutic options have been proposed for
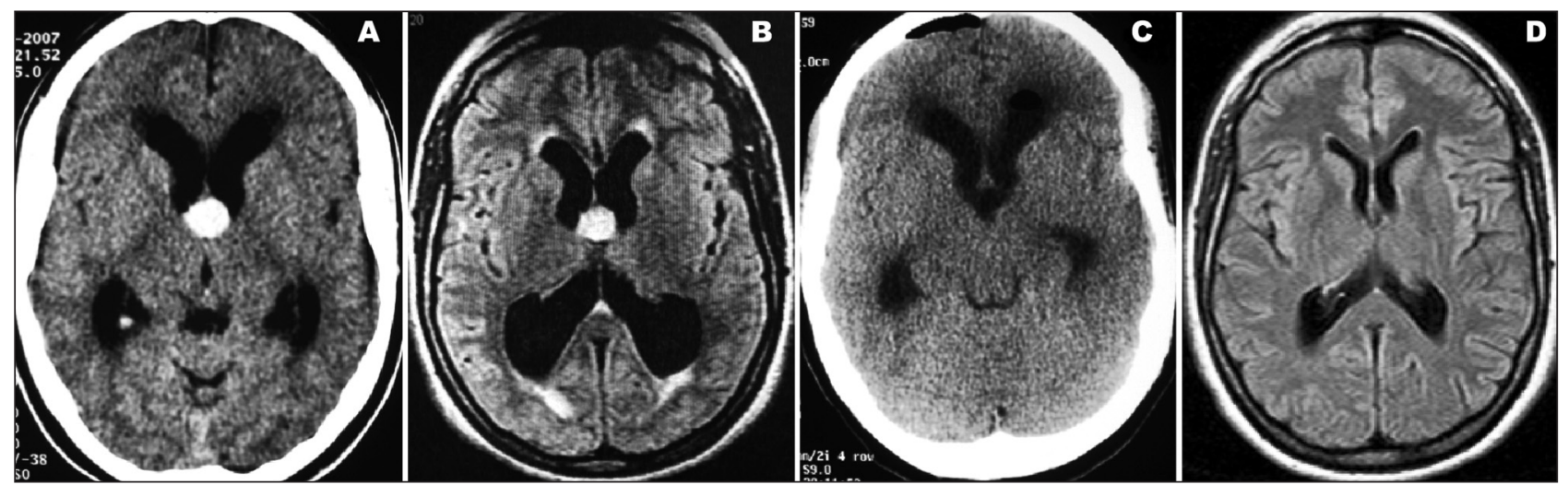

Fig 3. Patient \#8: [A] Pre-operative CT of a 36 years old, female demonstrating hydrocephalus and a $17 \mathrm{~mm}$ colloid cyst of the third ventricle; [B] Pre-operative MRI, Flair, demonstrating hydrocephalus, transependymal edema and a $17 \mathrm{~mm}$ colloid cyst of the third ventricle; [C] First post-operative CT scan of the head showing complete removal of the colloid cyst, without evidence of blood in the surgical field, small pneumocephalus and reduction of the ventricles size; [D] Three month post-operative MRI, Flair, no tumor, no hydrocephalus and normal ventricles size. 
asymptomatic and symptomatic patients. Non-surgical treatment and control image sequence can be the right attitude in asymptomatic cases, when the colloid cyst is small and the foramen of Monro is wide and no hydrocephalus is present ${ }^{5}$. Shunting of cerebrospinal fluid, stereotactic aspiration of its content, microsurgical removal, stereotactic-guided endoscopy, neuroendoscopy, stereotactically-guided craniectomy and neuronavigationassisted endoscopy have been proposed for symptomatic patients ${ }^{2-6,9-13}$.

Shunting is not recommended because the frequent problems related with the valves and the surgical procedures in the bilateral obstruction of the foramen of Monro requires bilateral ventricular shunting and it is not a curative treatment ${ }^{5,7}$.

Open surgical excision of the colloid cyst was first successfully carried out by Walter Dandy in 1921. Microsurgical procedures are considered the gold standard for total removal by some authors ${ }^{3,5}$. The transcortical approach, the transcallosal approach and the infratentorial-supracerebellar approach are the conventional techniques proposed for their removal".

In 1975, Gutierrez-Lara et al first performed the freehand puncturing of a colloid cyst and stereotactic aspiration was reported by Bosch in 1978. Stereotactically-guided aspiration should be performed in exceptional cases, because they often fail when the cyst content is hard ${ }^{3,7,73-15}$. The success of aspiration is around $52 \%{ }^{5}$, and it is less effective than the open microsurgical or endoscopic procedures and the recurrence rate is high $(62 \%)^{5,7,15,16}$. This means that it can be indicated in patients with severe accompanying diseases 5 .

In 1983, Pawer et al.,12 reported the first successful endoscopy aspiration of a third ventricle colloid cyst and after that, other authors replaced the open surgical procedures by endoscopy $y^{4,13,17}$. The endoscopic removal is considered the therapy of choice, due to the satisfactory outcome $\mathrm{e}^{3-5,13,17}$, minimal rate of complications, short hospitalization time ${ }^{16}$, earlier return to the work and the reduced costs ${ }^{4,5,13,17-19}$. Several endoscopic equipments have been described, but in general, the rigid endoscope is highly recommended and the most frequently used one $e^{3,5,7,8,16,20,21}$. Neuronavigation-assisted endoscopy has shown to be an accurate and safe method ${ }^{3,8,22-25}$.

The authors' intention is to reduce the invasiveness of intracranial procedures, while preventing brain tissue trauma in order to decrease the risk of neurological and mental deficits. The intracranial endoscopy proved to be a minimally-invasive technique that provides rapid access to the target via a small burr hole without the need for brain retraction, in contrast to craniotomy and microsurgical brain splitting and dissection that often causes injuries to the nervous tissues.
The endoscopic view may provide valuable additional information about the individual anatomy, which is not possible with the microscope; additionally, the aid of special instruments and bipolar diathermy, even highly vascularized lesions may be treated.

Laser is another interesting tool, useful for dissection or coagulation in many surgical procedures. It may also allow the resection of cyst capsule without causing bleeding or damage to the fornix, hypothalamus or the deep brain structures. The Nd:YAG laser has a $1064 \mathrm{~nm}$ wave length and it can penetrate $2.0 \mathrm{~mm}$ and $4.8 \mathrm{~mm}$ in the tissue when employed in the contact and non-contact modes, respectively. A $30^{\circ}$ neuroendoscopy lens may provide a contralateral view of the capsule inside the third ventricle, enabling the use of the laser with direct visualization of all treated structures. The stereotactic method increases the safety of the laser application; considering the known limits of the lesion, the laser application to undesired structures can be prevented. In 1989, Abernathey et al. combined conventional and stereotactic techniques and achieved the total removal of the colloid cysts in twelve patients. They used bipolar cautery or defocused laser power to promote hemostasis. No mortality and minimal morbidity have been associated with the procedures and there was no evidence of recurrence in an average follow-up period of 19 months'. In 1992, Merienne et al. reported on four intraventricular lesions (two colloid cysts of the third ventricle, one arachnoidal cyst and one intraventricular meningioma) surgically treated by endoscopic laser-therapy in stereotactic conditions. The laser beam (Nd:YAG) was used as a surgical knife on cystic lesions and also to vaporize the meningioma ${ }^{26}$.

The stereotactic-guided neuroendoscopy and Nd:YAG techniques were used in seven of our eleven cases of colloid cysts and it ensured the safety of the use of laser inside the ventricles. The contact laser was very effective for hemostasis and the contact / non-contact laser were very useful to vaporize the empty cyst capsule. The total removal of the colloid cysts was possible without mortality or any evidence of recurrence in an average follow-up period of 33 months. The complications reported were such as intraoperative hemorrhage, memory deficit, mutism, third cranial nerve palsy, ventriculitis, seizures, venous infarction, fornix and thalamus contusion, transient or permanent hemiparesis and subdural fluid accumulation ${ }^{3,5,12,13,27,28}$. In our series, only two patients presented transient morbidities that were easily treated: one had Diabetes insipidus that lasted for two days and was treated with a single dose of DDAVP, and another had chemical aseptic meningitis, probably due to the contact of the cyst content with the CSF. This patient was treated with antibiotics and corticosteroids with complete resolution of the problem without sequels. 
In conclusion, neuroendoscopic stereotactic-guided resection of the third ventricle colloid cysts is a very accurate, simple, safe and efficient treatment method. The Nd:YAG laser allowed total removal of the capsule without bleeding or neural damage.

Nd:YAG laser technology should be incorporated in the repertoire of the surgical instruments usually used in minimally-invasive surgery. It can be coupled to an endoscope that allows direct intraoperative visualization and monitoring the precise effects of the surgical maneuvers and its action is perfectly controllable, especially in areas where surgical traumatism must be avoided, such as the region of the fornices and the hypothalamus.

\section{REFERENCES}

1. Abernathey CD, Davis DH, Kelly PJ. Treatment of colloid cysts of the third ventricle by stereotaxic microsurgical laser craniotomy. J Neurosurg 1989;70:525-529.

2. Badie B, Brooks N, Souweidane M. Endoscopic and minimally microsurgycal approaches for trating brain tumors patients. J Neurooncol 2004;69:209-219.

3. Hellwig D, Bauer B, Schulte M, Gatscher S, Riegel T, Bertalanaffy H. Neuroendoscopy treatment for colloid cysts of the third ventricle: the experience of a decade. Neurosurgery 2003;52:525-533.

4. Johnson RR, Baehring J, Joseph P. Surgery for third ventricular tumors. Neurosurg Quart 2003;13:207-225.

5. Kehler U. Twenty colloid cysts: comparison of endoscopic and microsurgical management. Minim Invas Neurosurg 2001;44:121-127.

6. Cabbell K, Ross D. Stereotactic microsurgical craniotomy for the treatment of third ventricular colloid cysts. Neurosurg 1996;38:301-307.

7. Decq P. Endoscopic management of colloid cysts. Neurosurgery 1998;42: 1288-1304.

8. Grunert P, Hopf N, Perneczky A. Frame-based and frameless endoscopic procedures in the third ventricle. Stereot Image-Guided Surg 1997;8:80-89.

9. Horváth Z, Vetö F, Balás I, Dóczi T. Complete removal of colloid cysts via CT-guided stereotactic biportal neuroendoscopy. Acta Neurochir 2000;142:539-546.

10. Jho H, Alfieri A. Endoscopic removal of third ventricular tumors: a technical note. Minim Invas Neurosurg 2002;45:114-119.

11. Konovalov A, Pitskhelauri D. Infratentorial supracerebelar approach to the colloyd cysts of the third ventricle. Neurosurgery 2001;49:1116-1123.
12. Vialogo JGG. Acesso endoscópico transepto-interforniceal para cistos colóides. Arq Neuropsiquiatr 2000;58:939-946.

13. Wuttipong T, Schulte D M, Bauer B L, Bertalanaffy H, Hellwig D. Neuroendoscopy surgery of intracranial cysts in adults. Childs Nerv Syst 2004;20:842-851.

14. Kondziolka D, Lunsford D. Stereotactic management of colloid cysts: factors predicting succes. J Neurosurg 1991;75:45-51.

15. Kumar K, Kelly M, Toth C. Stereotactic cyst wall disruption and aspiration of colloid cysts of the third ventricle. Stereotact Funct Neurosurg 1998;71:145-152

16. Rodziewicz G, Smith M, Hodge C. Endoscopic colloid cysts surgery. Neurosurgery 2000;46:655-662.

17. Schroeder H, Gaab M. Endoscopic resection of colloid cysts. Neurosurgery 2002;51:1441-1445.

18. Zamorano L, Chavantes MC, Dujovny M, Ausman J. Image guided stereotatic ressection of intracranial lesion: endoscopic and laser technique. In: Neurosurgery State of Art Reviews. Philadelphia: Hauley \& Belfus, 1989:105-118.

19. Zhang Y, Wang C, Liu P, Gao X. Clinical aplication of neuroendoscopic techniques. Stereotact Funct Neurosurg 2000;75:133-141.

20. King W, Ullman J, Frazee J, Kalmon D, Bergsneider M. Endoscopic resection of colloid cysts;surgical considerations using the rigid endoscope. Neurosurgery 1999;44:1103-1109.

21. Morita A, Okada Y, Kitano M, Hori T, Taneda M, Kirino T. Development of hybrid integrated endoscope-holder system for endoscopic microsurgery. Neurosurgery 2004;55:926-932.

22. Gonzalez-Martinez JA, Zamorano L, Diaz FG. Interactive image-guided management of colloid cysts of the third ventricle. Minim Invas Neurosurgery 2003;46:193-197.

23. Harris A, Hadjipanayis C, Lunsford D, Lunsford A, Kassam A. Microsurgical removal of intraventricular lesion using endoscopic visualizatioin and stereotactic guidance. Neurosurgery 2005;56(Suppl 1):S125-S132.

24. Shroeder H, Wagner W, Tschiltschke W, Gaab M. Framless neuronavigation in intracranial endoscopic neurosurgery. J Neurosurgery 2001;94: 72-79.

25. Zamorano L, Chavantes MC, Jiang Z, Kadi AM, Diaz F. Stereotactic neuroendoscopy. In: Cohen A (Ed). Concepts in neurosurgery: minimally invasive techniques in neurosurgery. New York: Williams \& Wilkins, 1995:49-65.

26. Merienne L, Leriche B, Roux FX, Devaux B. Treatment of colloid cysts of the third ventricle by stereotaxic microsurgical laser craniotomy. J Neurosurg 1989;70:525-529.

27. Shroeder H, Niendorf W, Gaab M. Complications of endoscopic third ventriculostomy. J Neurosurg 2000;96:1032-1040.

28. Mathiesen T, Grane P, Lindquist C, et al. High recurrence rate following aspiration of colloid cysts in the third ventricle. J Neurosurg 1993; 78:748-752. 